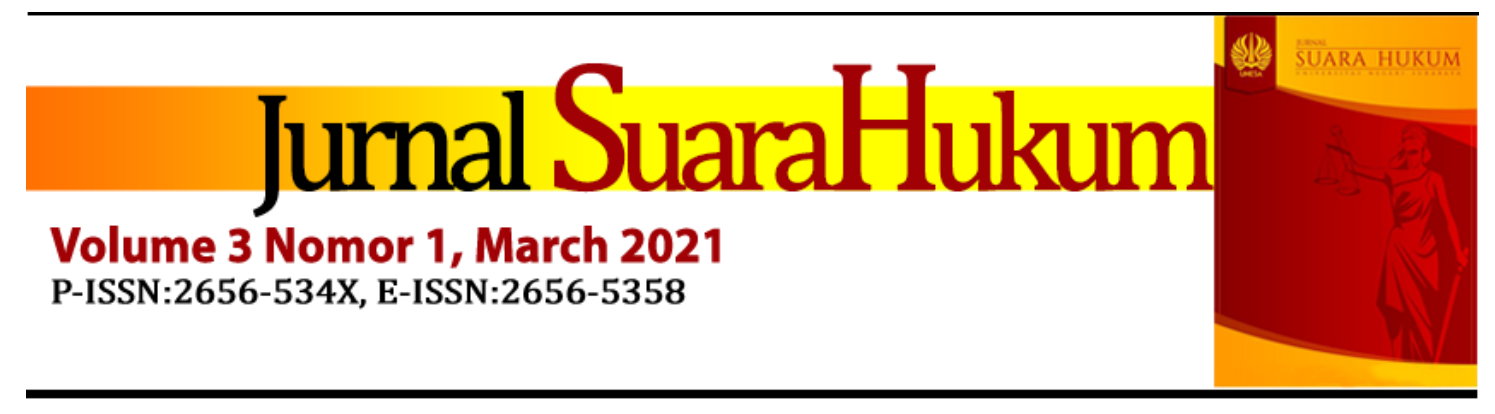

\title{
Perlindungan Hukum Bagi Pemegang Hak Merek Superman Terhadap Pelanggaran Merek
}

\author{
Viona Talitha Syafira \\ Fakutas Hukum, Universitas Indonesia, Salemba, Indonesia, \\ viona.talitha01@ui.ac.id
}

Article history:

Received: 10 December 2020 | Last Revision: 20 February 2021 | Accepted: 23 February 2021

\begin{abstract}
Owners of well-known marks in Indonesia have in some cases been rejected when submitting their application for registration by DGIP because most of the similar marks have already been registered. For example, PT. Marxing Fam Makmur by registering the Superman trademark while it was registered first by DC Comics. So, the problem is how the protection of Superman's trademark rights holders based on Law No. 20 of 2016, and how is the decision of the Commercial Court judge in ruling on trademark disputes. This study uses normative research methods which are sourced from secondary data as a support for qualitative analysis. Based on the analysis, it is known that the Superman brand belongs to PT. Marxing Fam Makmur has similarities in essence to the Superman brand owned by DC Comics and the Superman trademark registrant has bad intentions, so DC Comics as the owner of the Superman mark has the right to file a trademark cancellation lawsuit to the Central Jakarta Commercial Court. In the lawsuit, DC Comics did not prepare the lawsuit accurately and clearly so that the lawsuit became vague and the judge decided that the lawsuit was declared unacceptable.
\end{abstract}

Keywords: Intellectual Property Rights, Trademarks, and Good Faith.

\section{Abstrak}

Pemilik Merek terkenal di Indonesia dalam beberapa kasus mendapat penolakan pada saat mengajukan permohonan pendaftarannya oleh DJKI karena sebagian besar merek yang mirip sudah didaftarkan terlebih dahulu. Seperti yang dilakukan oleh PT. Marxing Fam Makmur dengan mendaftarkan merek Superman. Hal ini menimbulkan 
masalah, yaitu bagaimana perlindungan pemegang hak merek Superman terkait dengan unsur goodwill berdasarkan Undang-Undang Nomor 20 Tahun 2016, dan bagaimana keputusan keputusannya. Hakim Pengadilan Niaga dalam memutus sengketa merek. Superman milik PT. Marxing Fam Makmur dengan merek Superman DC Comics. Penelitian ini menggunakan metode penelitian normatif yang bersumber dari data sekunder sebagai penunjang analisis kualitatif. Berdasarkan hasil analisis diketahui bahwa merek Superman milik PT. Marxing Fam Makmur pada intinya memiliki kesamaan dengan merek Superman DC Comics dan pendaftar merek Superman memiliki niat yang tidak baik, sehingga DC Comics sebagai pemilik merek Superman berhak untuk mengajukan gugatan pembatalan merek ke Pengadilan Niaga Jakarta Pusat. Dalam gugatannya, DC Comics tidak menyusun gugatan secara akurat dan jelas sehingga gugatan tersebut menjadi kabur dan hakim memutuskan bahwa gugatan tersebut dinyatakan tidak dapat diterima.

Kata Kunci: Hak Kekayaan Intelektual, Merek Dagang, dan Itikad Baik.

\section{A. PENDAHULUAN}

Merek memiliki peranan penting bagi kehidupan manusia, selain itu merek telah menjadi bagian yang tidak dapat terpisahkan dalam suatu produk perdagangan baik barang maupun jasa. Dimanapun kita berada merek akan selalu melekat pada suatu produk yang berada disekitar kita, mulai dari kebutuhan pakaian, makanan, hingga transportasi yang kita pilih (Suyud Margono, 2013). Sebagai bagian yang sangat penting dalam kehidupan masyarakat saat ini, merek memberikan jaminan nilai atau kualitas dari barang dan jasa yang bersangkutan. Hal ini tidak hanya berguna bagi produsen pemilik merek tersebut, tetapi juga memberikan perlindungan dan jaminan mutu barang kepada produsen (Agung Indriyanto, 2017).

Merek merupakan salah satu wujud dari kekayaan intelektual, hak kekayaan intelektual merupakan suatu hak kebendaan yang mana hak tersebut bersumber dari hasil kerja otak dan rasio manusia. Hasil dari kerjanya itu berupa benda tidak berwujud (immaterial) sehingga hasil kerja otak itulah yang disebut sebagai intelektualitas (OK 
Saidin, 2013). Pada umumnya hukum kekayaan intelektual memberikan perlindungan gagasan-gagasan dari penggunaan atau peniruan oleh orang yang tidak berhak (Suyud Margono, 2013). Merek digunakan untuk membedakan suatu barang maupun jasa yang diproduksi oleh suatu perusahaan dengan tujuan untuk menunjukan ciri-ciri maupun asal usul barang tersebut. Terlebih disebabkan oleh perkembangan dunia teknologi yang sangat pesat sehingga membawa umat manusia pada zaman yang serba instan dengan dilakukannya promosi maka pemasaran wilayah barang pun akan semakin luas. Dengan demikian eksistensi sebuah merek menjadi hal yang sangat penting yang bertujuan untuk membedakan kualitas maupun asal usul barang tersebut.

Pengaturan yang mengatur hal-hal mengenai Hak Kekayaan Intelektual terdapat dalam ilmu hukum yang dinamakan Hukum KI, yang dimana Hukum KI tersebut meliputi bidang hukum yang membidangi hak-hak yuridis dari karya cipta hasil olah pikir manusia yang berkaitan dengan kepentingan ekonomi dan moral (Eddy Damian, 2003). Dari segi hukum, perlu diketahui bahwa yang dilindungi oleh hukum adalah KI, bukan objek material bentuk jelmaan KI. Alasannya adalah KI merupakan Hak Eksklusif yang hanya dimiliki dan melekat pada pemilik atau pemegang hak, apabila pihak lain ingin menggunakan atau memanfaatkan hak tersebut untuk menciptakan atau memproduksi objek material yang telah dilindungi HKI tersebut maka wajib memperoleh lisensi (izin) dari pemilik atau pemegang hak (Abdul Kadir, 2001).

Dalam konsep Hak Merek maka faktor yang menjadi alasan melekatnya hak tersebut yaitu adanya suatu ciptaan yang berdasarkan intelektual manusia melahirkan suatu produk tertentu maka diberikannya suatu merek terhadap produk tersebut. Hal ini untuk membedakan kualitas/ciri khas produk tertentu maka diberikan suatu merek 
P-ISSN: 2656-534X, E-ISSN: 2656-5358

Jurnal Suara Hukum, Vol. 3, No. 1, Maret 2021

sehingga produk tersebut dapat dibedakan dengan merek lainnya (Suyud Margono, 2002).

Untuk memperkenalkan produksi suatu perusahaan, merek memegang peranan penting bagi pemilik suatu produk. Selain untuk membedakan antara suatu barang/ jasa terhadap barang/ jasa lainnya, merek juga dapat membangun loyalitas konsumen yang antara lain merek dapat meyakinkan konsumen untuk dapat mengidentifikasi dengan mudah barang-barang yang ingin mereka beli. Kemudahan dalam mengidentifikasi barang tersebut dapat menghemat waktu dan biaya serta dapat menciptakan suatu persaingan pasar yang bebas. Beberapa pendapat menyatakan bahwa merek dagang adalah inti dari suatu kompetisi dalam meyakinkan konsumen. Merek membedakan produksi yang saling bersaing serta mendorong produsen untuk meningkatkan kualitas demi memperoleh keuntungan karena reputasi yang baik (H. D. Effendy Hasibuan, 2003).

Merek perlu dilindungi oleh hukum karena merek mempunyai nilai ekonomi terhadap suatu barang dan jasa dalam dunia perdagangan, serta membedakan value atau kualitas dengan barang dan jasa milik orang lain (H. D. Effendy Hasibuan, 2003). Dengan perlindungan tersebut maka akan terwujud keadilan yang menjadi tujuan dari hukum. Salah satu tujuan hukum adalah mewujudkan keadilan masyarakat. Dengan perlindungan hukum maka pemilik merek yang sah terlindungi hak-haknya (Enny Mirfa, 2017). Untuk mendapatkan perlindungan hukum maka merek harus didaftarkan. Dengan terdaftarnya merek yang sah di mata hukum maka merek tersebut terlindungi sebagai dasar penolakan terhadap merek yang sama secara keseluruhan atau sama pada pokoknya yang dimohonkan oleh orang lain dengan iktikad tidak baik untuk barang atau jasa sejenis. Namun tidak sedikit merek yang didaftarkan melanggar karya kekayaan 
intelektual lainnya seperti Hak Cipta, hal ini sangat jelas terlihat dari adanya persaingan dalam berbagai hal dengan cara yang tidak sehat yang dimana Hak Cipta tersebut dijadikan sebuah merek. Banyak upaya yang dilakukan oleh pihak-pihak yang tidak bertanggung jawab demi memenuhi kepentingannya sendiri, salah satunya adalah seperti kasus merek Superman milik DC Comics Amerika, DC Comics adalah penerbit komik terbesar dan terkenal di Amerika dan di dunia yang berdiri sejak tahun 1934. DC Comics selaku pemilik dan pemegang Hak Atas Merek Superman diluar wilayah Indonesia mengajukan gugatan pembatalan merek terhadap PT. Marxing Fam Makmur atas dasar penggunaan kata Superman sebagai merek dagang dalam menjalankan usahanya.

Mulanya, PT. Marxing Fam Makmur selaku tergugat merupakan perusahaan asal Indonesia dan juga pemegang hak eksklusif dimana tergugat mendapatkan Hak Atas Merek yang mengandung kata Superman dari pendaftar pertama yaitu Sutien Susilawati dengan cara jual beli. Memang pada kenyataannya tidak ada satu pihak pun yang mendaftarkan merek dengan nama Superman sebelum Sutien Susilawati, sehingga Sutien Susilawati merupakan orang pertama yang mendaftarkan nama Superman sebagai merek di Indonesia. Dikarenakan sistem perlindungan hukum merek di Indonesia bersifat "first to file" dengan pengertian bahwa apabila merek tersebut didaftarkan pertama kali maka disanalah merek tersebut dilindungi dan pihak tersebut berhak atas merek yang bersangkutan (Syprianus Aristeus, 2010). Pendaftar pertama akan mendapatkan hak esklusifnya selama 10 (sepuluh) tahun dengan konsekuensi tidak ada seorang pun yang boleh menggunakan merek tersebut untuk kepentingan komersial dari hak ekslusif tersebut tanpa seizin pemilik atau pemegang hak merek (sulastri, 2018). 
DC Comics selaku pemegang Hak Atas Merek Superman merasa telah dirugikan karena tidak adanya izin yang diajukan oleh Sutien Susilawati maupun PT. Marxing Fam Makmur untuk menggunakan nama Superman sebagai merek dagang usahanya. Hal ini jelas sudah melanggar hak moral DC Comics selaku pemegang Hak Atas Merek Superman yang telah diakui oleh dunia.

Kondisi saat ini banyak para pemilik merek terkenal dari luar wilayah Indonesia yang ingin mendaftarkan mereknya di Indonesia. Akan tetapi permohonan tersebut ditolak oleh Ditjen KI dengan alasan sudah terlebih dahulu terdaftarnya merek yang diajukan yang mengandung persamaan pada pokoknya terhadap permintaan pendaftaran merek untuk barang yang sejenis maupun tidak sejenis. Hal ini dapat dilihat dari kasus yang sedang diangkat yaitu kasus merek terkenal Superman milik DC Comics yang hendak mendaftarkan mereknya ke Ditjen KI namun pendaftaran tersebut ditolak karena sudah terdapat merek dengan nama serupa yang telah terdaftar. Hal ini tentu merugikan satu pihak karena telah menghalangi pemilik merek sesungguhnya untuk mengajukan permohonan pendaftaran atas merek terkenal miliknya.

DC Comics mengajukan gugatan kepada PT Marxing Fam Makmur ke Pengadilan Niaga yang terletak di Jakarta Pusat untuk membela hak nya sebagai pencipta dari tokoh Superman tersebut. Gugatan yang diajukan tersebut merupakan gugatan yang berkaitan dengan pembatalan merek oleh DC Comics untuk merek Superman, ataupun Logo S, serta Superman dan lukisan yang didaftarkan PT Marxing Fam Makmur di Dirjen Hak Kekayaan Intelektual Kemenkumham, gugatan tersebut diajukan pada 3 April 2018 di Pengadilan Niaga Jakarta Pusat dengan Nomor Perkara 17/Pdt.SusHKI/Merek/2018/PN Niaga Jkt.Pst. 
Jika dapat dibuktikan bahwa merek dan logo Superman milik PT. Marxing Fam Makmur benar meniru secara keseluruhan atau sama pada pokoknya dengan merek Superman milik DC Comics, maka berdasarkan Undang-undang Nomor 20 Tahun 2016 tentang Merek dan Indikasi Geograis PT. Marxing Fam Makmur dapat dikenakan sanksi dan dicoret dari daftar umum pemegang Hak Atas Merek yang telah diberikan oleh Ditjen KI karena telah melakukan pelanggaran Hak Atas Merek. Sehingga menimbulkan kerancuan apakah Undang-Undang Merek tersebut sudah berlaku dengan semestinya.

Berdasarkan latar belakang di atas maka permasalahan yang diangkat, yaitu: Bagaimana perlindungan pemegang hak merek Superman dikaitkan dengan unsur iktikad baik dalam Undang-Undang No. 20 Tahun 2016 tentang Merek dan Indikasi Geografis dan Bagaimana putusan hakim Pengadilan Niaga mengenai sengketa pemegang Hak Merek Superman berdasarkan Undang-Undang No. 20 Tahun 2016 tentang Merek dan Indikasi Geografis.

\section{B. METODE PENELITIAN}

Tipe penelitian ini merupakan penelitian normatif melalui pendekatan UndangUndang. Penelitian normatif merupakan penelitian hukum yang dilakukan dengan cara meneliti bahan pustaka atau data sekunder (Soekanto, 2003). Pemahaman dan pengaturan akan ditinjau dengan Undang-Undang Nomor 20 Tahun 2016 tentang Merek dan Indikasi Geografis. Penelitian yang digunakan adalah penelitian deskriptif, dimaksudkan untuk memberikan data seteliti mungkin tentang manusia, keadaan atau gejala-gejala lainnya (Soekanto, 2015). 
Penelitian ini memerlukan data sekunder yang didukung dengan data primer yang diperoleh langsung dari sumber pertama, yakni perilaku warga masyarakat, melalui wawancara (Soekanto, 2015). Data sekunder diperoleh melalui studi kepustakaan, mencakup dokumen-dokumen resmi, buku-buku, dan hasil-hasil penelitian yang berwujud laporan (Soekanto, 2015).

Pengumpulan data melalui wawancara dengan Kasubdit Pelayanan Hukum dan Fasilitasi Komisi Banding Merek Direktorat Jenderal Kekayaan Intelektual, wawancara ini dilakukan untuk mendapatkan penjelasan secara resmi dari pihak Ditjen KI terkait dengan alasan dikabulkannya permohonan pendaftaran merek Superman yang diajukan oleh PT Marxing Fam Makmur. Hasil data dari penelitian ini dianalisis dengan metode kualitatif yaitu apa yang dinyatakan oleh responden secara tertulis atau lisan, dan perilaku nyata yang diteliti dan dipelajari adalah obyek penelitian yang utuh (Soekanto, 2015). Analisis dilakukan dengan menguraikan keseluruhan data hasil dari penelitian yang akan menjawab permasalahan dalam penelitian.

Pengambilan kesimpulan dilakukan dengan menggunakan cara berpikir deduktif, yaitu kegiatan berpikir dari pernyataan yang bersifat umum ditarik kesimpulan yang bersifat khusus (Izhar, 2016).

\section{HASIL DAN PEMBAHASAN}

Pengertian merek atau brand menurut Undang-Undang Nomor 20 Tahun 2016 tentang Merek dan Indikasi Geografis Pasal 1 angka 1 yaitu suatu tanda atau simbol yang terdiri dari nama, istilah, gambar, logo, lambang, desain atau kombinasi dari semua itu yang ditujukan untuk mengidentifikasi, mendefinisi atau memberi identitas kepada suatu barang atau jasa dari suatu penjual serta membedakannya dari pesaing. 
Berdasarkan definisi di atas, maka merek itu sendiri secara umum dapat diartikan secara tegas bahwa merek adalah suatu tanda pembeda untuk barang-barang sejenis yang dihasilkan atau diperdagangkan oleh seseorang atau sekelompok orang atau badan hukum atas barang-barang sejenis yang dihasilkan orang lain. Merek selain berfungsi untuk daya pembeda dapat juga berguna sebagai jaminan atas mutu yang digunakan dalam perdagangan barang dan jasa (O.K. Saidin, 1997).

Merek pada hakikatnya adalah suatu tanda akan tetapi agar tanda tersebut dapat diterima sebagai merek, harus memiliki daya pembeda. Yang dimaksud dari daya pembeda itu sendiri adalah memiliki kemampuan untuk digunakan sebagai tanda yang dapat membedakan hasil perusahaan yang satu dengan perusahaan yang lain (O.K. Saidin, 1997). Dengan melihat objek yang dilindungi dari merek, maka merek berfungsi untuk membedakan barang yang dibuat dan diproduksi oleh suatu perusahaan atau jasa yang dihasilkan. Dengan demikian, merek merupakan tanda pengenal yang digunakan oleh perusahaan untuk melakukan kegiatan perdagangan dan juga untuk menjamin mutu suatu barang dan/atau jasa apabila dibandingkan dengan barang dan/atau jasa yang diproduksi oleh perusahaan lain (Rachmadi Usman, 2003).

Dalam literatur hukum dikenal dua macam sistem pendaftaran merek, yaitu pendaftaran merek dengan sistem deklaratif dan pendaftaran merek dengan sistem konstitutif (Rachmadi Usman, 2003). Dalam sistem konstitutif, hak atas merek diperoleh melalui pendaftaran. Apabila melakukan pendaftaran atas merek dengan sistem ini, maka seseorang akan mendapatkan hak eksklusif dari merek tersebut (Rachmadi Usman, 2003). Hal ini harus dilakukan karena tanpa pendaftaran maka pelaku usaha tersebut tidak ada hak atas merek maupun perlindungan hukum atas mereknya (Suhargon, 2019). Maka dalam sistem ini dikatakan bahwa hak atas merek 
P-ISSN: 2656-534X, E-ISSN: 2656-5358

Jurnal Suara Hukum, Vol. 3, No. 1, Maret 2021

terbentuk karena pendaftaran dan bukan karena pemakaian pertama (OK Saidin, 2013). Sedangkan dalam sistem deklaratif, pendaftaran merek bukanlah hal yang wajib dilakukan karena tidak ada kewajiban untuk melakukannya (OK Saidin, 2013). Dalam sistem ini, seseorang yang berhak atas merek adalah orang-orang yang dengan sungguhsungguh menggunakan merek tersebut dengan baik. Pendaftaran merek bagi sistem ini hanyalah untuk dugaan bahwa pihak yang mereknya terdaftar itu adalah pihak yang berhak atas merek tersebut dan sebagai pengguna pertama dari merek yang didaftarkan (OK Saidin, 2013).

Indonesia menganut sistem konstitutif, karena dengan melakukan pendaftaran ke Direktorat Jenderal Kekayaan Intelektual akan memberikan jaminan atas perlindungan hukum dan kepastian hukum. Jika merek telah terdaftar, siapapun pihak tidak dapat menggugat merek tersebut (Rachmadi Usman, 2003). Terkait dengan pendaftaran merek, terdapat syarat-syarat yang harus dipenuhi bagi pihak-pihak yang akan mendaftarkan mereknya agar merek tersebut diterima oleh Direktorat Jenderal Kekayaan Intelektual (OK Saidin, 2013). Syarat pertama yang harus dipenuhi adalah merek harus memiliki daya pembeda yang cukup kuat untuk membedakan dengan produksi barang atau jasa milik pihak lain (OK Saidin, 2013).

Pelanggaran terhadap merek merupakan suatu perbuatan yang dilakukan untuk mendapatkan keuntungan yang besar dan mudah, yaitu dengan berusaha mengikuti, meniru atau memalsukan merek tertentu yang sudah terkenal di kalangan masyarakat. Hal ini dapat mengakibatkan kerugian tidak hanya bagi masyarakat dan produsen atau pengusaha, tetapi negara pun juga dirugikan (Muhammad Djumhana, 1997). Pelanggaran merek adalah perbuatan yang secara tanpa hak menggunakan merek 
terdaftar, yang mempunyai persamaan pada pokoknya atau keseluruhan untuk barang atau jasa yang sejenis (Gunawan Widjaja, 2002).

\section{Kasus Posisi}

Sengketa ini bermula ketika DC Comics selaku penggugat hendak mendaftarkan merek Superman ke Kementerian Hukum dan HAM, lalu ditemukan permasalahan bahwa merek "Superman" milik PT. Marxing Fam Makmur dalam hal ini selaku tergugat telah terlebih dahulu melakukan pendaftaran di Indonesia tertanggal 7 Maret 1993 dalam kelas 30 dan kelas 34, merek tersebut terdaftar dengan No. Agenda IDM000374439 dan IDM000374438 yang pada awal mulanya pemilik merek tersebut adalah Sutien Susilawati. Merek "Superman" tersebut telah dilakukan perpanjangan pada tahun 2003 dan 2013, yang kemudian pada tahun 2013 pemilik merek Sutien Susilawati mengalihkan merek tersebut kepada PT. Marxing Fam Makmur melalui jual beli sebagaimana perjanjian jual beli merek No. 37 tertanggal 22 Maret 2013. Memang pada kenyataannya tidak ada satu pihak pun yang mendaftarkan merek dengan nama “Superman” sebelum Sutien Susilawati, sehingga Sutien Susilawati merupakan orang pertama yang mendaftarkan nama Superman sebagai merek di Indonesia. Indonesia menganut prinsip first to file dengan pengertian suatu prinsip dimana pemilik merek akan mendapatkan perlindungan hak atas merek akibat telah didaftarkan pertama kali.

Berdasarkan penemuan tersebut DC Comics mengajukan keberatan terhadap merek "Superman" yang telah terdaftar yaitu dalam kelas 30 dan kelas 34 dengan No. Agenda IDM000374439 dan IDM000374438 dan juga mengajukan keberatan atas pendaftaran merek oleh PT. Marxing Fam Makmur dengan nomor agenda D002015034068; Merek siantar top superman choco ; nomor agenda D002015034070; 
P-ISSN: 2656-534X, E-ISSN: 2656-5358

Jurnal Suara Hukum, Vol. 3, No. 1, Maret 2021

Merek siantar top superman chocomax; nomor agenda D00201534066 dengan tanggal pendaftaran 11 agustus 2015 dikelas 30 .

DC Comics selaku pemilik merek "Superman" tidak dapat menerima keadaan tersebut, menurutnya merek "Superman” milik PT. Marxing Fam Makmur tidak dapat didaftarkan karena adanya merek "Superman" miliknya yang mana merupakan merek terkenal. Hal ini diperkuat dengan telah didaftarkannya merek Superman milik DC Comics dinegara asalnya yaitu Amerika Serikat pada tahun 1939 dan telah terdaftar pula di berbagai Negara di dunia seperti Australia, Brazil, Inggris, Jepang, Kanada, Mauritius, Meksiko, Rusia, Uni Emirat Arab, Yaman, Argentina, dan Afrika Selatan. Pendaftaran merek di berbagai Negara tersebut membuat merek "Superman" milik DC Comics dapat dikatakan sebagai merek terkenal, hal tersebut didukung dengan adanya Yurisprudensi Mahkamah Agung RI Nomor 1486/K/Pdt/1991 tertanggal 25 November 1995 yang menyatakan sebagai berikut:

"Suatu merek termasuk dalam pengertian Well-Known Mark pada prinsipnya diartikan bahwa merek tersebut telah beredar keluar dari batas-batas regional malahan sampai batas-batas transnasional, karenanya apabila terbukti suatu merek telah terdaftar di banyak negara dunia, maka dikwalifisir sebagai merek terkenal karena telah beredar sampai area batas-batas di luar Negara asalnya."

Merujuk dari Yurisprudensi tersebut tidak dapat disangkal lagi bahwa merek "Superman" milik DC Comics adalah sebuah merek terkenal, yang mempunyai keistimewaan tersendiri di berbagai negara tempat merek "Superman" terdaftar atau negara berikutnya yang menjadi negara tujuan didaftarkan merek "Superman" tersebut. DC Comics menduga bahwa PT. Marxing Fam Makmur melakukan perbuatan curang dengan mendaftarkan merek "Superman" yang mana mempunyai persamaan pada 
pokoknya dengan merek "Superman" milik DC Comics. PT. Marxing Fam Makmur diduga melakukan tindakan curang yang bertujuan untuk mendapatkan keuntungan berlebih, maka dari itu DC Comics mengajukan pembatalan merek terhadap merek “Superman” milik PT. Marxing Fam Makmur ke Pengadilan Niaga Jakarta Pusat.

Pembatalan merek akan memberikan akibat hukum dan berakhirnya perlindungan hukum atas merek. Pengajuan pembatalan merek dapat dilakukan dengan mengajukan gugatan kepada pengadilan niaga di Jakarta, diajukan antara lain oleh pihak yang memiliki legal persona standi in judicio yaitu:

a. Pihak yang berkepentingan atas merek tersebut (pemilik merek terdaftar, jaksa, lembaga konsumen, lembaga bidang keagamaan).

b. Pemilik merek yang tidak terdaftar (pemilik merek terkenal tetapi mereknya tidak terdaftar) setelah mengajukan permohonan kepada Menteri

DC Comics selaku pemilik merek "Superman" atas dasar tersebut mengajukan pembatalan terhadap merek "Superman" milik PT. Marxing Fam Makmur ke Pengadilan Niaga Jakarta Pusat, dikarenakan kedudukan pemilik merek "Superman" berada diluar wilayah Republik Indonesia. Gugatan pembatalan yang diajukan pemilik merek "Superman" didasarkan atas alasan-alasan sebagai berikut:

1. Merek Superman, Logo S, dan Superman + Lukisan adalah merek terkenal yang harus dilindungi di Indonesia.

2. Merek Superman yang terdaftar milik PT. Marxing Fam Makmur diduga bertujuan untuk membonceng keterkenalan merek "Superman" milik DC Comics. 
3. Merek "Superman" milik PT. Marxing Fam Makmur mempunyai kemiripan dan persamaan pada pokoknya dengan unsur utama dari merek "Superman" milik DC Comics, yaitu dengan adanya bentuk tulisan dan lukisan karakter yang sama.

4. Merek "Superman" milik PT. Marxing Fam Makmur seharusnya dibatalkan karena mempunyai persamaan pada pokoknya dengan merek terkenal “Superman” milik DC Comics untuk barang sejenis maupun tidak sejenis.

Keberatan dengan gugatan yang dilayangkan oleh DC Comics, PT. Marxing Fam Makmur mengajukan eksepsi dengan dalil bahwa gugatan tersebut telah daluarsa (lewat waktu). Bahwa pada faktanya merek "Superman" milik PT. Marxing Fam Makmur telah terdaftar di tanggal 7 Maret 1993 dimana jika dihitung sampai dengan gugatan yang diajukan maka merek "Superman” milik PT. Marxing Fam Makmur telah terdaftar lebih dari 25 (dua puluh lima) tahun dan telah dilakukan proses prepanjangan pada tahun 2013. Sehingga dengan demikian gugatan yang diajukan oleh DC Comics telah daluwarsa (lewat waktu).

Dalil selanjutnya menyatakan bahwa PT. Marxing Fam Makmur selaku tergugat keberatan atas gugatan yang dilayangkan oleh DC Comics karena gugatan pembatalan pendaftaran merek yang diajukan oleh DC Comics masih terlalu dini (premature) dan gugatan terhadap merek Superman miliknya merupakan gugatan Exception Obscuur Libel (kabur dan tidak jelas) mengingat pada gugatan tersebut DC Comics pada pokoknya meminta pembatalan merek. Bahwa DC Comics mendasarkan tujuan mengajukan gugatan adalah untuk membatalkan merek-merek milik PT. Marxing Fam Makmur yang telah terdaftar di Ditjen KI yaitu No. Agenda IDM000374439 dan IDM000374438, namun dalam posita halaman 4 (empat) putusan Pengadilan Niaga DC 
Comics selaku penggugat juga mengajukan keberatan dengan pendaftaran merek yang telah didaftarkan PT. Marxing Fam Makmur dengan nomor agenda:

a. D002015034068 Merek Siantar Top Superman Choco

b. D002015034070 Merek Siantar Top Superman Chocomax

c. D002015034066 dengan tanggal pendaftaran 11 Agustus 2015 di kelas 30

Merek-merek tersebut saat ini telah ditolak oleh Ditjen KI pada tanggal 13 Desember 2017 karena tidak diterima saat dilakukan pemeriksaan substantif oleh pejabat pemeriksa atas permohonan pandaftaran merek milik PT. Marxing Fam Makmur. Dengan demikian upaya hukum yang harus dilakukan terhadap merek tersebut adalah mengajukan banding ke Komisi Banding Merek bukan gugatan yang bersifat pembatalan. Gugatan tersebut dikatakan prematur karena belum waktunya gugatan tersebut diajukan, melainkan harus menunggu adanya putusan dari Komisi Banding Merek.

Dengan demikian PT. Marxing Fam Makmur tidak dapat menerima gugatan DC Comics karena DC Comics selaku penggugat telah mencampur adukan antara gugatan pembatalan merek dengan upaya hukum keberatan/banding merek, dimana upaya hukum tersebut seharusnya dipisahkan dengan upaya hukum pembatalan merek, sehingga dengan demikian gugatan DC Comics tidak menyebutkan secara jelas dan lengkap objek gugatan.

Terkait eksepsi yang diajukan oleh PT. Marxing Fam Makmur selaku tergugat dan pemegang merek terdaftar Superman maka Pengadilan Niaga Jakarta Pusat pada putusan Nomor 17/Pdt.Sus-Merek/2018/PN.Niaga.Jkt.Pst yang amarnya menerima dan mengabulkan eksepsi yang diajukan sepanjang mengenai gugatan yang masih teralu dini (premature) dan gugatan yang kabur dan tidak jelas. Berdasarkan uraian dan 
P-ISSN: 2656-534X, E-ISSN: 2656-5358

Jurnal Suara Hukum, Vol. 3, No. 1, Maret 2021

pertimbangan-pertimbangan tersebut Majelis Hakim berpendapat bahwa gugatan yang diajukan penggugat dalam hal ini DC Comics tidaklah disusun dengan cermat dan jelas sehingga mengakibatkan gugatan menjadi kabur.

\section{Putusan Hakim Pengadilan Niaga Mengenai Sengketa Pemegang Hak Merek} Superman Berdasarkan Undang-Undang No. 20 Tahun 2016 Tentang Merek dan Indikasi Geografis

Pelaku usaha yang akan membangun maupun baru memulai suatu usaha, akan berusaha membuat merek tersebut dapat dikenal dan menjadi pembeda dikalangan barang-barang sejenisnya. Dalam dunia usaha yang berkaitan dengan merek, masih banyak pengusaha yang mengambil jalan pintas atau jalur cepat untuk mendomplen dan menaikkan nilai suatu merek dengan cara membonceng suatu merek yang sudah terkenal (Bustani \& Wangsa, 2019). Cara yang diambil oleh pelaku usaha tersebut akan merugikan pihak lain terutama pemilik asli merek yang sudah bersusah payah membangun mereknya menjadi merek terkenal.

Sebagai pihak yang dirugikan, pemegang hak atas merek tentu akan menempuh jalur hukum untuk menyelsaikan kasus pelanggaran merek. Hal tersebut bertujuan agar pelaku pelanggaran merek tidak akan lagi memakai merek yang menyerupai pada pokoknya atau keseluruhannya dari merek terkenal atau bakan mengentikan aktivitas produksinya (Meli Hertati Gultom, 2018).

Berdasarkan lembaga pengawasan dari Amerika Serikat USTR (United States Trade Representative), Indonesia masuk dalam negara empat besar terkait tingginya angka pembajakan hak kekayaan intelektual di dunia, kerugiannya bisa mencapai Rp. 65.100.000.000.000,00 (Tristiawati, 2021). Tingginya kasus merek di atas menunjukan bahwa merek mempunyai nilai ekonomis yang tinggi. Produk 
yang diberi merek merupakan kekayaan immaterial dari perusahaan yang dapat menaikan pendapatan (OK Saidin, 2013). Hal ini sering dimanfaatkan oleh competitor yang memiliki iktikad tidak baik untuk mendompleng, membajak, meniru untuk mengambil keuntungan dengan cara yang singkat (Durianto, 2011). Terlebih lagi, Indonesia merupakan surga bagi produk-produk bajakan sehingga cenderung tidak menghargai suatu merek baik merek barang maupun merek jasa (Fajar et al., 2018). Hal ini seringkali membuat pemilik barang maupun jasa yang ingin mendapatkan keuntungan materi secara berlebih memilih menggunakan merek yang sudah terkenal sebelumnya.

Pengertian pemohon yang beriktikad tidak baik dalam penjelasan Pasal 21 ayat (3) Undang-Undang Merek No.20 tahun 2016 dapat diartikan Pemohon yang dalam mendaftarkan mereknya memiliki niat untuk meniru, menjiplak, maupun mengikuti merek pihak lain untuk kepentingan usahanya sendiri sehingga dapat menimbulkan persaingan usaha tidak sehat, ataupun menyesatkan konsumen.

Menafsirkan iktikad tidak baik sebaiknya tidak dibatasi dalam penjelasan Pasal 21 ayat (3) Undang-Undang No. 20 tahun 2016 saja, karena dapat mereduksi tindakan yang dapat dikualifikasikan sebagai iktikad tidak baik. Baik atau tidak baiknya suatu iktikad baik dalam hal pendaftaran merek tidak hanya dilihat dari unsur-unsur pasal namun harus juga dilihat dari tindakan yang secara nyata dilakukan oleh pemohon merek itu sendiri (Agung Indriyanto, 2017).

Dalam kasus merek Superman, penilaian atas merek Superman merupakan merek terkenal atau tidak harus ditinjau terlebih dahulu melalui beberapa aspek, mengenai penilaian atas merek terkenal, Ditjen KI menyatakan bahwa merek Superman milik DC Comics bukanlah merek terkenal, menurut Ditjen KI merek 
P-ISSN: 2656-534X, E-ISSN: 2656-5358

Jurnal Suara Hukum, Vol. 3, No. 1, Maret 2021

Superman milik DC Comics hanya memenuhi salah satu unsur atau kriteria merek terkenal yaitu telah mendaftarkannya di beberapa negara dunia seperti Amerika, Australia, Brazil, Inggris, Jepang, Kanada, Mauritius, Meksiko, Rusia, Uni Emirat Arab, Yaman, Argentina, dan Afrika Selatan sebagaimana dinyatakan dalam Putusan Pengadilan Niaga Jakarta No. 17/Pdt.Sus-Merek/2018/PN.Niaga.Jkt.Pst. Sehingga merek tersebut sesuai dengan Pasal 21 (1) hurub (b) Undang-Undang No.20 tahun 2016 yang didalam penjelasannya terdapat kriteria merek terkenal meliputi beberapa hal sebagai berikut:

1. Pengetahuan umum masyarakat mengenai merek tersebut

2. Reputasi merek yang diperoleh akibat promosi yang dilakukan secara gencar

3. Investasi yang dilakukan oleh pemilik merek di beberapa negara di dunia

4. Bukti pendaftaran merek di beberapa negara yang dilakukan oleh pemiliknya, Dalam hal ini DC Comics telah menginvestasikan mereknya dibeberapa negara di dunia seperti: Amerika, Australia, Brazil, Inggris, Jepang, Kanada, Mauritius, Meksiko, Rusia, Uni Emirat Arab, Yaman, Argentina, dan Afrika Selatan.

Berhubungan dengan pendaftaran merek di beberapa negara, pemilik merek yang hendak mendaftarkan mereknya diluar negeri dapat dilakukan melalui tiga alternatif. Tiga pilihan tersebut dapat berupa jalur nasional, jalur regional, dan jalur internasional. Jalur internasional atau dapat juga dikenal sebagai Protocol Madrid, Protocol Madrid menjadi pilihan yang lebih komprehensif bagi para pemilik merek yang hendak mendaftarkan mereknya diluar negeri melalui sistem pendaftaran yang terintegrasi. Dengan dibentuknya Protocol Madrid terdapat dua 
tujuan utama, yaitu untuk memfasilitasi pemilik merek agar mudah mendapatkan perlindungan merek yang bersifat global dan untuk menyederhanakan proses pendaftaran merek yang cukup dilakukan dengan satu permohonan dalam satu bahasa, satu mata uang dan satu prosedur (Agung Indriyanto, 2017). Dalam hal ini merek Superman milik DC Comics telah melakukan pendaftaran merek dibeberapa negara di dunia, namun yang perlu dipahami bahwa Protocol Madrid tidak menggantikan substansi hukum merek nasional di masing-masing negara. Sistem ini hanyalah prosedur alternatif yang diberikan kepada pemilik merek yang hendak mendaftarkan mereknya di luar negeri. Dengan kata lain, jalur internasional ini dapat digunakan secara berdampingan dengan jalur nasional dan regional.

Ditjen KI menyampaikan bahwa merek yang telah terdaftar berdasarkan hukum di Indonesia tidak semerta-merta menjadi merek terkenal, mengingat merek Superman milik PT. Marxing Fam Makmur yang merupakan objek sengketa dalam kasus ini sudah terdaftar lebih dari 20 tahun. Dalam hal ini terdapat beberapa kekeliruan yang dilakukan Kantor Merek selaku pejabat fungsional yang memiliki tugas untuk melakukan pemeriksaan substantif terhadap permohonan pandaftaran merek. Kekeliruan tersebut dikarenakan Kantor Merek telah mengabulkan permohonan pendaftaran merek Superman milik PT. Marxing Fam Makmur tanpa mengindahkan pasal-pasal lain secara keseluruhan yang terdapat dalam Undang-Undang Merek No.20 tahun 2016. Menurut Ditjen KI pendaftaran merek Superman milik PT. Marxing Fam Makmur dapat dikatakan sebagai pemohon yang beriktikad baik apabila telah memenuhi syarat permohonan sesuai dengan syarat dan tata cara yang tercantum dalam Pasal 4 
P-ISSN: 2656-534X, E-ISSN: 2656-5358

Jurnal Suara Hukum, Vol. 3, No. 1, Maret 2021

Undang-Undang Merek no.20 tahun 2016 tanpa melihat adanya penjelasan Pasal 21 ayat (2) Undang-Undang Merek No.20 tahun 2016 yang menyatakan permohonan ditolak jika diajukan oleh pemohon yang beriktikad tidak baik.

Penjelasan mengenai permohonan yang beriktikad tidak baik adalah suatu tindakan yang disengaja untuk meniru dengan sengaja sebagian atau seluruhnya merek yang telah terdaftar sebelumnya dengan tujuan agar merek yang didaftarkan tersebut dapat menyamai kepopuleran merek yang ditiru tersebut untuk keuntungan pendaftar merek yang beritikad tidak baik tersebut (Damian, 2006).

PT. Marxing Fam Makmur telah melakukan pendaftaran merek Superman yang memiliki persamaan pada pokoknya dengan merek terkenal Superman milik DC Comics baik dari segi tulisan tiga dimensi yang sama maupun persamaan bunyi ucapan yang terdapat dalam merek tersebut. Namun Ditjen KI tetap mengabulkan permohonan pendaftaran merek tersebut dan berpendapat bahwa merek Superman milik DC Comics bukanlah merek terkenal, karena kriteria yang lebih dominan atau lebih utama mengenai merek terkenal dapat dilihat dari pengetahuan umum masyarakat disuatu negara terhadap merek terkenal tersebut, sehingga Ditjen KI menganggap bahwa merek Superman bukan merupakan merek terkenal dikarenakan banyak masyarakat Indonesia tidak mengetahui keberadaan merek Superman tersebut sebagai merek untuk jenis barang tertentu yang sudah generic (Damian, 2006).

Sebagian lapisan masyarakat berpendapat lain dan menyatakan bahwa merek Superman merupakan merek terkenal sehingga PT. Marxing Fam Makmur telah melakukan pendaftaran dengan iktikad tidak baik dan sudah sepatutnya 
Kantor Merek tidak menyetujui permohonan pendaftaran merek Superman karena PT Marxing Fam Makmur bukanlah pemohon yang mempunyai iktikad baik, hal ini dibuktikan dengan ditiru atau dijiplaknya merek Superman milik DC Comics yang telah terdaftar di beberapa Negara seperti Amerika, Australia, Brazil, Inggris, Jepang, Kanada, Mauritius, Meksiko, Rusia, Uni Emirat Arab, Yaman, Argentina, dan Afrika Selatan. Berdasarkan hal tersebut, merek Superman milik PT. Marxing Fam Makmur telah melanggar ketentuan dari Pasal 21 ayat (3) Undang-Undang Merek No.20 tahun 2016.

Undang-undang merek beserta penjelasannya telah memadai sebagai arahan dalam pelaksaaan pendaftaran merek. Namun pada praktiknya masih banyak pemilik merek yang merasa dirugikan karena pelaksanaannya tidak objektif, kolutif, penuh dengan rekayasa di tingkat teknik dan administratif (Budi, 2008). Dari kasus-kasus yang telah diputus di pengadilan Indonesia sering ditemukan permasalahan dalam luasnya ruang interpretasi pada arti "persamaan pada pokoknya", sehingga pengaplikasian undang-undang merek menjadi sangat subjektif dan tidak terukur. Hal ini dapat dilihat dari unsur itikad baik yang ada pada Undang-Undang Merek.

Kekuatan unsur iktikad baik dalam permohonan pendaftaran merek di Indonesia masih sangat lemah, mengingat kantor merek tidak dapat menolak permohonan pendaftar merek jika telah memenuhi syarat dan tata cara permohonan sesuai prosedur dalam Pasal 4 Undang-Undang Merek. Menurut Ditjen KI Jika pemohon pendaftaran merek telah melengkapi segala syarat dan tata cara permohonan pendaftaran, maka pemohon tersebut dapat dikatakan sebagai pendaftar dengan iktikad baik. Dari segi hukum pelaksanaan iktikad baik 
pendaftaran merek hanya tercantum dalam Pasal 21 ayat (3) Undang-Undang No.20 tahun 2016 tentang Merek dan Indikasi Geografis. Sehingga kekuatan unsur iktikad baik seseorang sulit dibuktikan pada saat melakukan permohonan pendaftaran merek karena keterbatasan pengetahuan pemeriksa merek di Ditjen KI akan merek-merek terkenal baik yang sudah didaftarkan maupun belum didaftarkan, tetapi unsur iktikad baik seseorang baru dapat dibuktikan setelah adanya pihak lain yang keberatan akan pendaftaran merek yang bersangkutan, barulah akan dilanjutkan dengan memberikan gugatan kepada Pengadilan Niaga Jakarta Pusat.

Kasus seperti ini terjadi di Indonesia dalam putusan Pengadilan Niaga Jakarta Nomor 17/Pdt.Sus-Merek/2018/PN.Niaga.Jkt.Pst, yakni yang terjadi pada merek dagang "Superman” untuk produk barang maupun jasa milik DC Comics. DC Comics adalah suatu persekutuan yang didirikan menurut Undang-Undang Negara Bagian New York, yang berkedudukan dan berkantor pusat di 2900 West Alameda Avenue, Burbank, California 91505, USA. Merek dagang "Superman" sudah terdaftar di Amerika sejak 10 Oktober 1939 serta di berbagai negara belahan dunia. Saat DC Comics hendak mendaftarkan mereknya di Indonesia pada tahun 2017 pendaftaran merek tersebut ditolak oleh kantor merek Direktorat Jenderal Hak Kekayaan Intelektual (HKI) yang disebabkan telah terdaftarnya produk dengan nama merek serupa yang telah didaftarkan atas nama PT. Marxing Fam Makmur sejak tanggal 7 Maret 1993, dengan sertifikat No. IDM000374439 dan No. IDM000374438.

Berdasarkan keterkenalan merek miliknya yang tidak dapat diragukan lagi maka pemilik merek dagang "Superman" yaitu DC Comics merasa keberatan 
dengan terdaftarnya merek dagang oleh pihak lain yang juga memiliki unsur kata "Superman" yang telah terdaftar pada tanggal 7 Maret 1993 atas nama PT. Marxing Fam Makmur. Dengan demikian DC Comics mengajukan gugatan ke Pengadilan Niaga Jakarta Pusat untuk menggugat PT. Marxing Fam Makmur yang telah memakai merek "Superman" yang pada umumnya sama, tetapi Putusan Pengadilan Niaga menolak gugatan yang diajukan oleh Penggugat.

Sistem perlindungan merek di Indonesia adalah first to file system, yang diatur dalam Pasal 3 Undang-Undang Merek No.20 tahun 2016 yang berbunyi hak atas merek diperoleh setelah Merek tersebut terdaftar. Bagi merek yang belum didaftarkan, merek bersangkutan tidak mendapatkan hak atas merek sebagai bentuk perlindungan hukum. Namun setelah mendapatkan hak atas merek, barulah mendapatkan perlindungan oleh Undang-Undang Merek dan Indikasi Geografis. Perlindungan merek biasa atau yang belum terkenal hanya dapat dilakukan jika pemilik merek telah mendaftarkan mereknya. Namun apabila terdapat pihak yang keberatan terhadap pendaftaran merek tersebut, upaya perlindungan yang diberikan oleh Undang-Undang merek yaitu dengan mengajukan gugatan pembatalan terhadap pendaftar merek yang beritikad tidak baik.

Perlindungan merek terkenal berbeda dengan perlindungan merek biasa karena perlindungan merek terkenal akan lebih pasti dalam mengetahui asal usul pendaftaran merek tersebut, saat pendaftar ingin melakukan pendaftaran suatu merek, Direktorat Jenderal Kekayaan Intelektual melakukan pemeriksaan terhadap seluruh merek yang sudah menjadi terkenal. Jika Ditjen KI menemukan adanya kesamaan pada pokoknya maupun kesamaan pada keseluruhannya, maka 
Ditjen KI akan langsung menolak pendaftaran tersebut karena pendaftar memiliki itikad tidak baik (Budi, 2008).

Bagi pemegang hak merek terkenal yang hendak mengajukan gugatan dan dapat membuktikan keterkenalan mereknya dalam proses pengadilan, UndangUndang Merek dan Indikasi Geografis menyediakan mekanisme gugatan pembatalan merek terdaftar melalui Pengadilan Niaga. Berdasarkan UU No.20/2016 Pasal 76 ayat (2) dan (3) Apabila merek terkenal mereka telah terlanjur didaftarkan oleh pihak yang beriktikad tidak baik di Indonesia, maka gugatan tersebut dapat diajukan setelah mengajukan permohonan kepada Menteri.

Gugatan pembatalan dan Gugatan Penghapusan memiliki perbedaan dalam pelaksanaanya. Gugatan pembatalan dapat dilakukan jika merek tersebut masih dilakukan oleh pihak lain dan masih melakukan produksi, perdagangan dan peredaran, sedangkan gugatan penghapusan dapat dilakukan jika merek tersebut tidak digunakan atau diproduksi secara berturut-turut selama 3 tahun terakhir setelah tanggal pendaftaran, hal ini sesuai dengan Pasal 74 Ayat (1) UndangUndang Nomor 20 Tahun 2016 Tentang Merek dan Indikasi Geografis. Dikarenakan merek "Superman" milik PT. Marxing Fam Makmur masih melakukan produksi dan barang tersebut masih diperdagangkan dan dierdarkan hingga saat ini, DC Comics mengajukan gugatan pembatalan merek Superman ke Pengadilan Niaga Jakarta Pusat. 


\section{Putusan Hakim Pengadilan Niaga Mengenai Sengketa Pemegang Hak Merek} Superman Berdasarkan Undang-Undang No. 20 Tahun 2016 Tentang Merek dan Indikasi Geografis

Sengketa merek yang memiliki persamaan pada pokoknya antara merek “Superman” milik DC Comics dengan merek "Superman” milik PT. Marxing Fam Makmur, Diajukan ke Pengadilan Niaga Jakarta Pusat oleh DC Comics sebagai penggugat selaku pemilik merek terkenal "Superman" dan yang menjadi tergugat ialah PT. Marxing Fam Makmur selaku Pemegang Hak Merek "Superman” di Indonesia tertanggal 3 April 2018 dengan nomor register perkara: 17/Pdt.SusMerek/2018/PN.Niaga.Jkt.Pst.

Hakim Pengadilan niaga Jakarta Pusat yang berwenang memutus perkara gugatan pembatalan merek "Superman" milik PT. Marxing Fam Makmur yang diajukan oleh pemilik merek terkenal "Superman” yaitu DC Comics menyatakan gugatan haruslah dinyatakan tidak dapat diterima (niet on vanklicht verklaard). Pertimbangan hakim dalam memutus perkara gugatan pembatalan merek "Superman" ialah bahwa gugatan yang diajukan penggugat tidaklah disusun dengan cermat dan jelas, yang mengakibatkan gugatan menjadi kabur.

Bahwa pada dasarnya Penggugat dalam gugatannya meminta pembatalan merek milik Tergugat yakni PT. Marxing Fam Makmur yang telah terdaftar di Ditjen KI, namun secara bersamaan Penggugat yakni DC Comics juga mengajukan keberataran dengan pendaftaran merek yang telah didaftarkan tergugat dengan Nomor Agenda: D002015034068, D002015034070, dan D00201534066. DC Comics juga mengajukan gugatan agar mengabulkan pendaftaran dan menerbitkan sertifikat merek-merek Superman atas nama 
P-ISSN: 2656-534X, E-ISSN: 2656-5358

Jurnal Suara Hukum, Vol. 3, No. 1, Maret 2021

Penggugat sesuai dengan permintaan pendaftarannya dengan nomor agenda DID2018015583， DID2018015584， DID201815589， DID201815591， DID201815593, dan DID201815594 yang diajukan pada tanggal 29 Maret 2018.

Faktanya, permohonan pendaftaran merek "Superman" dengan nomor agenda D002015034068, D002015034070, dan D00201534066 dengan tanggal pendaftaran 11 Agustus 2015 di kelas 30 telah ditolak permohonannya oleh Ditjen KI pada tanggal 13 Desember 2017. Bahwa berdasarkan ketentuan Pasal 28 ayat (1) UU Merek yang pada pokoknya menyatakan bahwa permohonan banding dapat diajukan terhadap penolakan berdasarkan alasan sebagaimana dimaksud dalam ketentuan Pasal 20 dan/atau Pasal 21 UU Merek. Maka dengan demikian upaya hukum yang seharusnya dilakukan oleh PT. Marxing Fam Makmur selaku tergugat adalah mengajukan Banding ke Komisi Banding Merek. Maka dari itu gugatan Penggugat telah mencampur adukan antara Gugatan Pembatalan merek dengan upaya keberatan/banding merek, dimana upaya hukum tersebut seharusnya dipisahkan dengan upaya hukum pembatalan merek, sehingga dengan demikian gugatan Penggugat tidak menyebutkan secara jelas dan lengkap objek gugatan. Bahwa gugatan yang diajukan atas obyek yang tidak jelas, fakta-fakta hukum yang tidak jelas harus dinyatakan tidak dapat diterima. Dimana hal tersebut sejalan dengan Yurisprudensi Tetap Mahkamah Agung RI No. 565/K/Sip/1973 tanggal 21 Agustus 1973 yang menyatakan hal sebagai berikut: "Kalau objek gugatan tidak jelas maka gugatan tidak dapat diterima”

Bahwa berdasarkan uraian dan pertimbangan-pertimbangan yang telah dijabarkan, sehingga hakim dalam memutus gugatan pembatalan yang dilakukan 
oleh DC Comics selaku penggugat tidak menyalahi aturan Undang-Undang Nomor 20 Tahun 2016 Tentang Merek Dan Indikasi Geografis.

\section{PENUTUP}

Berdasarkan hasil penelitian, maka simpulan dan saran yang dapat penulis uraikan, yaitu. Pertama, dalam pelaksanaan pendaftaran merek di Indonesia, tidak ada cakupan untuk menentukan iktikad baik dalam melakukan pendaftaran merek. Ditjen KI berpendapat bahwa setiap pendaftar di anggap memiliki iktikad baik selama telah memenuhi semua persyaratan yang terdapat dalam Pasal 4, 5, dan 6 Undang-Undang Merek No. 20 tahun 2016. Hal ini tidak ada alasan bagi Ditjen KI untuk menolak pendaftar yang telah memenuhi semua persyaratan yang dituangkan dalam pasal-pasal tersebut. Dalam memberikan penilaian terhadap persamaan pada pokoknya bagi merek yang telah didaftarkan, dapat dilakukan dengan menitikberatkan pendaftaran merek yang dilakukan dengan unsur iktikad baik tanpa ada niat untuk melakukan pemboncengan terhadap merek tertentu di dalam proses pendaftaran. Kedua, hakim Pengadilan niaga Jakarta Pusat yang berwenang memutus perkara gugatan pembatalan merek "Superman" milik PT. Marxing Fam Makmur yang diajukan oleh pemilik merek terkenal "Superman" yaitu DC Comics menyatakan gugatan haruslah dinyatakan tidak dapat diterima (niet on vanklicht verklaard). Pertimbangan hakim dalam memutus perkara gugatan pembatalan merek "Superman" ialah bahwa gugatan yang diajukan penggugat tidaklah disusun dengan cermat dan jelas, yang mengakibatkan gugatan menjadi kabur. Alasan yang menyebabkan gugatan menjadi kabur dikarenakan penggugat meminta pembatalan merek milik tergugat yakni PT. Marxing Fam Makmur yang telah terdaftar di Ditjen KI, namun secara bersamaan penggugat juga mengajukan 
P-ISSN: 2656-534X, E-ISSN: 2656-5358

Jurnal Suara Hukum, Vol. 3, No. 1, Maret 2021

keberataran dengan pendaftaran merek yang telah didaftarkan tergugat. Maka dari itu gugatan Penggugat telah mecampur adukan antara Gugatan Pembatalan merek dengan upaya keberatan/banding merek, dimana upaya hukum tersebut seharusnya dipisahkan dengan upaya hukum pembatalan merek, sehingga dengan demikian gugatan Penggugat tidak menyebutkan secara jelas dan lengkap objek gugatan.

Berdasarkan simpulan tersebut, maka saran yang dapat diberikan terhadap kasus ini, bahwa merek-merek yang hendak didaftarkan harus selalu disosialisasikan secara luas agar masyarakat dapat mengetahui merek-merek mana yang telah terdaftar sehingga tidak ada lagi gugatan terhadap merek yang mempunyai persamaan pada pokoknya. Kinerja pemeriksa merek di Kementerian Hukum dan Hak Asasi Manusia, Direktorat Jenderal Hak Kekayaan Intelektual lebih ditingkatkan guna menghindari terjadinya kecurangan, dan lebih meningkatkan ketelitian dalam melakukan pemeriksaan setiap permohonan pendaftaran merek agar tidak ada lagi merek-merek yang mempunyai persamaan pada pokoknya dengan merek lain baik dengan merek biasa maupun merek terkenal. 


\section{DAFTAR PUSTAKA}

\section{Buku}

Abdul Kadir. (2001). Kajian Hukum Ekonomi Hak Kekayaan Intelektual. PT Citra Aditya Bakti.

Agung Indriyanto. (2017). Aspek Hukum Pendaftaran Merek. Raja Grafindo Persada.

Budi, H. S. (2008). Hak Kekayaan Intelektual. PT. Penerbit Buku Kompas.

Damian, E. (2006). Hak Kekayaan Intelektual. PT. Alumni.

Durianto, D. (2011). Strategi Menaklukkan Pasar Melalui Riset Ekuitas Perilaku Merek. Gramedia Utama Pustaka.

Eddy Damian. (2003). Hukum Hak Cipta. Alumni.

Gunawan Widjaja. (2002). Lisensi atau Waralaba: Suatu Panduan Praktis. PT Raja Grafindo Persada.

H. D. Effendy Hasibuan. (2003). Perlindungan Merek: Studi Mengenai Putusan Pengadilan Indonesia dan Amerika Serikat. Program Pasca Sarjana Fakultas Hukum Universitas Indonesia.

Muhammad Djumhana. (1997). Hak Milik Intelektual (Sejarah, Teori dan Prakteknya di Indonesia)(revisi). PT Citra Aditya Bakti.

O.K. Saidin. (1997). Aspek Hukum Hak Kekayaan Intelektual. PT Raja Grafindo Persada.

OK Saidin. (2013). Aspek Hukum Kekayaan Intelektual (Intellectual Property Rights). Raja Grafindo Persada.

Rachmadi Usman. (2003). Hukum Hak Atas Kekayaan Intelektual: Perlindungan dan Dimensi Hukumnya di Indonesia. PT. Alumni.

Soekanto, S. (2003). Penelitian Hukum Normatif: Suatu Tinjauan Singkat. PT Raja Grafindo Persada.

Soekanto, S. (2015). Pengantar Penelitian Hukum. Penerbit Universitas Indonesia.

Suyud Margono. (2002). Pembaharuan Perlindungan Hukum Merek. Novindo Pustaka Mandiri.

Suyud Margono. (2013). Hukum Hak Kekayaan Intelektual. Pustaka Eka Cipta.

Syprianus Aristeus. (2010). Perlindungan Merek Terkenal sebagai Aset Perusahaan. Badan Pembinaan Hukum Nasional.

\section{Artikel Jurnal}

Bustani, S., \& Wangsa, T. F. (2019). Perlindungan Pemilik Merek Dagang Eik Yang Digunakan Di Indonesia Melalui Perjanjian Distributor (Analisis Putusan Nomor 1300 K/Pdt.Sus_Hki/2017). Era Hukum - Jurnal Ilmiah Ilmu Hukum, 17(2), 362383. https://doi.org/10.24912/erahukum.v17i2.6001 
Enny Mirfa. (2017). Perlindungan Hukum Terhadap Merek Yang Terdaftar. Jurnal Hukum Samudera Keadilan, 2(1), 67. https://doi.org/10.26623/jic.v5i1.2217

Fajar, M., Nurhayati, Y., \& Ifrani, I. (2018). Iktikad Tidak Baik Dalam Pendaftaran Dan Model Penegakan Hukum Merek Di Indonesia. Jurnal Hukum Ius Quia Iustum, 25(2), 219-236. https://doi.org/10.20885/iustum.vol25.iss2.art1

Izhar. (2016). Mengidentifikasi Cara Berpikir Deduktif Dan Induktif Dalam Teks Bacaan Melalui Pengetahuan Koteks Dan Referensi Pragmatik. Jurnal Pesona, 2(1), 65-66.

Meli Hertati Gultom. (2018). Perlindungan Hukum Bagi Pemegang Hak Atas Merek Terhadap Pelanggaran Merek. Mimbar Warta Edisi:56, April, 97-108.

Suhargon, R. (2019). Analisa Hukum Terhadap Pentingnya Pendaftaran Hak Merek Dagang Bagi UMKM Dalam Rangka Meningkatkan Perekonomian Rakyat (Berdasarkan Undang-Undang No. 20 Tahun 2016 tentang Hak Merek dan Indikasi Geografis). JURNAL MUQODDIMAH: Jurnal Ilmu Sosial, Politik Dan Hummaniora, 3(2), 67. https://doi.org/10.31604/jim.v3i2.2019.67-73

Sulastri. (2018). Perlindungan Hukum Terhadap Merek (Tinjauan Terhadap Merek Dagang Tupperware Versus Tulipware). Jurnal Yuridis, 5(Juni), 166.

\section{Website}

Tristiawati, P. (2021). Pembajakan Hak Intelektual di Indonesia Masuk 4 Besar Dunia. Www.Liputan6.Com. https://www.liputan6.com/news/read/2527345/pembajakan-hak-intelektual-diindonesia-masuk-4-besar-dunia

\section{Peraturan Perundang-Undangan Dan Putusan}

Sekretaris Negara Republik Indonesia. (2016). Undang-Undang Nomor 20 Tahun 2016 tentang Merek dan Indikasi Geografis (Lembaran Negara Republik Indonesia Tahun 2016 Nomor 252, Tambahan Lembaran Negara Republik Indonesia Nomor 5953). Jakarta: Menteri Hukum dan Hak Asasi Manusia Republik Indonesia.

Putusan Pengadilan Niaga Jakarta No. 17/Pdt.Sus. Merek/2018/PN.Niaga.Jkt.Pst 